\title{
Volatile displacement of Meghalaya coals - A pointer to explore low sulphur coals
}

\author{
P BEHERA \\ P.G. Department of Geology, Utkal University, Bhubaneswar 751 004, India. \\ e-mail:pn_behera@indiatimes.com
}

\begin{abstract}
Volatile displacement, which measures the difference between calculated and experimental volatile matter, is indicative of abnormality in coals which may be related to petrological or chemical parameters. The volatile displacement $(\delta v)$ values of Meghalaya coals were calculated from their chemical analyses. Correlations of volatile displacement $(\delta v)$ with parameters such as carbon, hydrogen, moisture, oxygen, oxygen plus sulphate sulphur, oxygen plus pyritic sulphur, oxygen plus organic sulphur and total sulphur were studied. An approximately linear relationship exists only between $\delta v$ and moisture, and $\delta v$ and total sulphur, and not between other parameters. Plots on Seyler's chart indicate the coals as perhydrous to orthohydrous. The linear relationship with total sulphur indicates that the coals may have become abnormal mainly due to the marine environment of deposition and weathering.
\end{abstract}

\section{Introduction}

Meghalaya in NE India (figure 1), has limited reserves of about 640 million tonnes of coal, of which Garo Hills alone has a share of 360 million tonnes. The annual production is about 35 lakh tonnes and the coal is mostly of the sub-bituminous type. The ash content of this coal is much lower than that of any high quality coal of the country and its calorific value exceeds some of the best grade coal. However, these coals are not considered good grade because of a high sulphur content which is a major drawback in metallurgical and other industrial uses.

Seyler (1938) devised a formula for the calculation of volatile matter (V.M.) from results of the ultimate analysis of carbon and hydrogen. His observation was that if the coal was a normal one, there will be negligible difference in the values of volatile matter found by experiment (Proximate Analysis) and that calculated by the formula. The bright coals do not show much variation between experimental V.M. and calculated V.M., but the dull coals of India rich in durain and clarain show large differences between experimental value and calculated value of volatile matter due to the complexity of its composition developed by weathering, heat effect and other related causes. These coals are termed as abnormal coals.

The volatile matter of coals can be calculated using the following formula:

$$
\text { V.M. }(\text { calculated })=10.61 \mathrm{H}-1.24 \mathrm{C}+84.15
$$

where

$$
\% \mathrm{H}=\text { Hydrogen } \% \mathrm{C}=\text { Carbon. }
$$

Volatile displacement $(\delta v)=$ Volatile matter (experimental) - V.M. (calculated).

In Seyler's (1938) chart (figure 2), a narrow band is drawn between the carbon limits $87-70 \%$ and hydrogen 2.0 to $5.8 \%$, which he believed to include the composition of all normal (humic) bright coals within this range of carbon content. The coals which show volatile matter displacement will fall outside Seyler's band drawn for normal coals and will be termed as abnormal coals.

Chandra and Srivastava (1980) studied the volatile displacement $(\delta v)$ and chemical

Keywords. Coal; volatile displacement; total sulphur; marine environment; Meghalaya; India. 


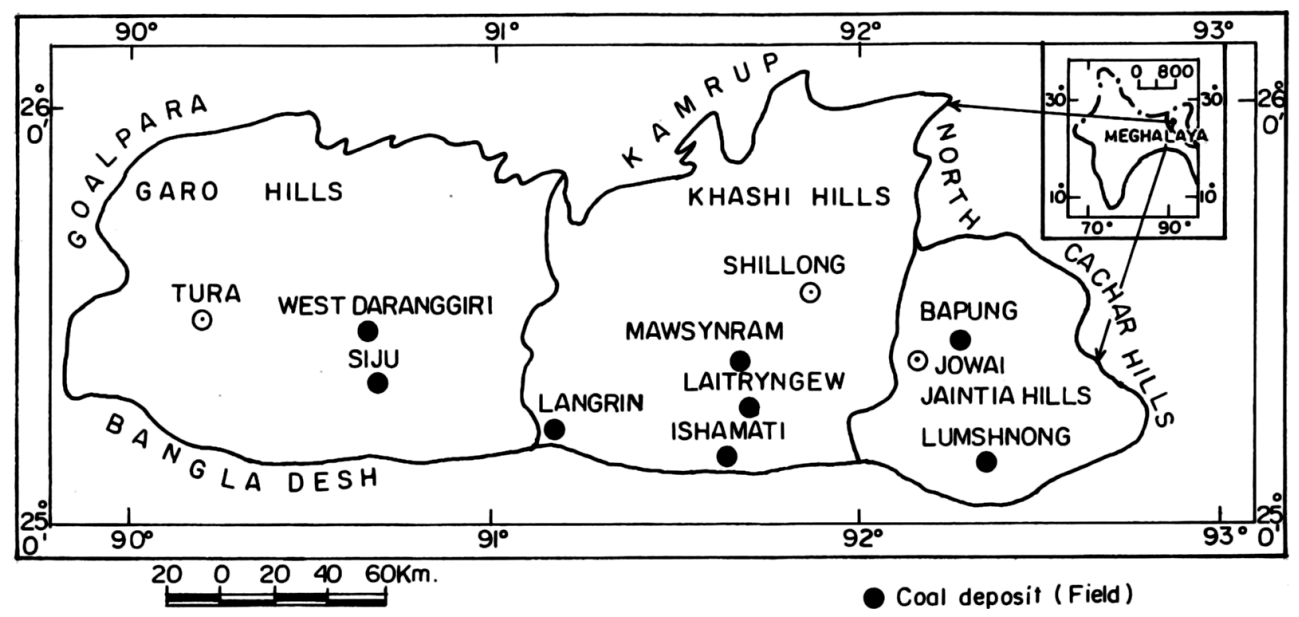

Figure 1. Coal map of Meghalaya (after Chandra et al 1983).

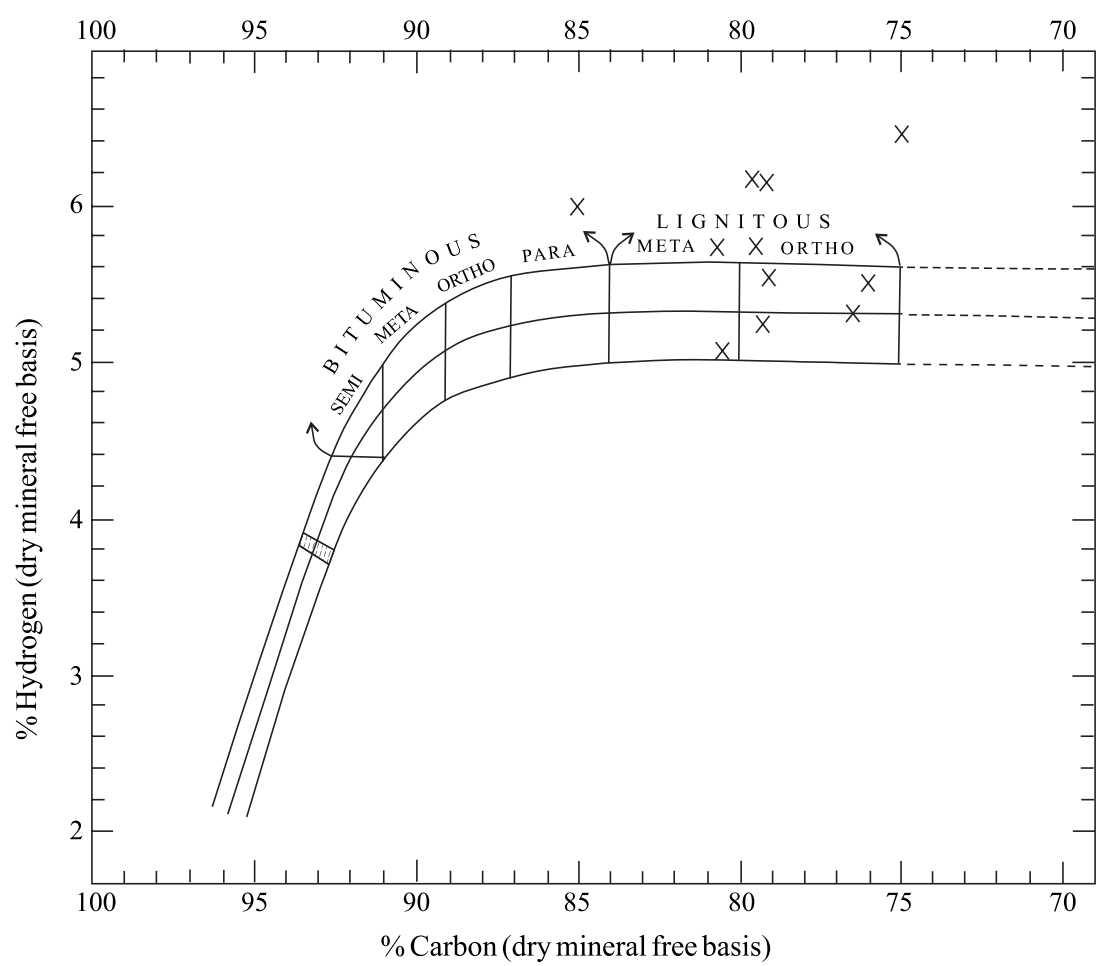

Figure 2. Plottings of Meghalaya coals on Seyler's Chart.

composition of burnt coals (coals either heated in presence of oxygen or carbonized in the laboratory under controlled conditions in the absence of oxygen) collected from Jharia coalfield, and found them abnormal. Chandra and Gupta (1976) also studied coal samples from the same field and observed that $\delta v$ occurs due to weathering or oxidation of coals. The Ib-valley coals of Orissa were also found to be abnormal (Behera 1991). Niyogi (1989) studied the Talcher coals of Orissa and found them abnormal due to weathering. It has been observed that if $\delta v$ is greater or less than \pm 2.5 , the coals are abnormally rich in durain (Seyler
1938), or are oxidized or weathered (Chandra and Srivastava 1980). Coal could be abnormal if it is rich in exinite, inertinite or high in hydrogen content (Chandra et al 1997).

Coals found in India belong to two geological formations, i.e., Gondwana and Tertiary. Coals found in these two geological formations show contrasting characters, may be due to their environment of deposition. Meghalaya coals belong to the Tertiary sequence of NE India.

The purpose of the present study is to find out the causes of abnormality of the Meghalaya coals and its relation to the sulphur content. 


\section{Methodology}

The published chemical data of Meghalaya coals by Chandra et al (1983) were used for the calculation of volatile matter and volatile displacement. The data for carbon percentage and hydrogen percentage were plotted on Seyler's Chart. Correlations between carbon and $\delta v$, hydrogen and $\delta v$, moisture and $\delta v$, oxygen and $\delta v$, oxygen plus sulphatesulphur and $\delta v$, oxygen plus pyritic sulphur and $\delta v$, oxygen plus organic sulphur and $\delta v$ and total sulphur and $\delta v$ were studied. Regression curves were drawn and values of correlation coefficients were computed in order to assess the degree of correlation between two variables (figure 3 ). To test the significance of the observed correlation coefficients, t-test was performed.

$$
t=R / \sqrt{ } 1-R^{2}(\sqrt{ }(N-2))
$$

where $t=$ test for significance, $R=$ correlation coefficient, $N=$ sample size.

The observed values of $t$ were compared with the tabulated values of $t$ at $5 \%$ and $1 \%$ levels of significance for $N-2$ degrees of freedom and conclusions were drawn accordingly.

\section{Results and discussion}

The coalfields of Meghalaya have been shown in table 1. The chemical analysis of Meghalaya coals is given in table 2. Oxygen and sulphur concentrations are shown in table 3 . The total sulphur content of the Meghalaya coals ranges from 1.99 to $6.83 \%$, the average being $3.64 \%$ (table 3 ). Besides, there is an upward increase of sulphur content from the bottom seam to the top seam. The top coal seams have a higher concentration than that of the bottom seams. For example, west Daranggiri, Siju, Laitryngew, Ishamati and Langrin coalfields have a lower concentration of pyritic sulphur and organic sulphur, whereas Bapung and Lumshnong coalfields have a higher concentration. Sulphate sulphur concentration shows no significant variation (table 3). Similarly, the total sulphur content is more in the eastern side of the coalfield, i.e., more in Bapung and Lumshnong coalfields.

Daranggiri and Siju coalfields are located in the western part of Meghalaya coal deposits, whereas Bapung, Lumshong, etc. are located in the eastern part. Stratigraphically, Bapung coalfield belongs to the Theria stage of Palaeocene age, and hence is the oldest in Meghalaya. Lumshong, Langrin, Mawsynram, Ishamati and Laitryngew coalfields belong to the Sylhet stage of lower to middle Eocene age. Siju and west Daranggiri coalfields belong to basal Tura stage of Lower Eocene age (table 2).
Pyritic sulphur content is found to increase from the western to the eastern part of Meghalaya, which is mainly due to the prevalent marine conditions at the time of deposition in the eastern part of the basin (Ghosh 1976). Coals of Meghalaya are characteristically high in sulphate sulphur content (0.18 to $0.73 \%)$. High sulphate sulphur content in coals of Meghalaya is conspicuous whenever there is a thin overburden. Comparatively, high sulphate sulphur may be due to the weathered nature of coals (Chandra et al 1983). The regional lateral variation of coals of Meghalaya is strictly a palaeoenvironmental effect. In other words, the increase in sulphur content from west to east is due to the more marine nature of the peatforming swamps of Khasi and Jaintia hills as compared to that of Garo hills (Chandra et al 1983).

The carbon and hydrogen plots of Meghalaya coals fall within and above the normal 'coal band' of Seyler's Chart (figure 2). Hence, the coals can be classified as lignitous coal with normal and above normal hydrogen content (perhydrous). Therefore, most of the coals are abnormal due to volatile displacement. Carbon and hydrogen were plotted against volatile displacement in figure 3 (a) and (b). The $R^{2}$ values were 0.34 and 0.0645 respectively. There was no significant correlation as the plots were scattered and $t$-test showed that the observed value of $t$ was less than the tabulated value (table 4). Oxygen was plotted against $\delta v$. in figure $3(\mathrm{c})$ and $R^{2}$ value was 0.5263 . No specific relation was found. Oxygen plus sulphate sulphur, oxygen plus pyritic sulphur and oxygen plus organic sulphur were plotted against $\delta v$ in figure 3 (d), (e), and (f) respectively. The plots were scattered and no specific relation was noted. Moisture versus $\delta v$ was drawn which showed a positive linear relation with $R^{2}$ value 0.5414 (table 4 ). The volatile displacement increases with the increase of moisture content (figure 3g). From this relation it can be construed that at the time of recession of the sea, $\delta v$ was mainly controlled by weathering. These plots of Meghalaya coals fall outside the normal line of Seyler's Chart. The $\delta v$ was plotted against total sulphur (figure $3 \mathrm{~h}$ ) which also showed no significant correlation, $R^{2}$ being 0.3799 .

All the above correlation coefficient values were subjected to $t$-tests for authentication of the conclusions by using the formula mentioned in methodology. The observed values were compared with tabulated values at $5 \%$ and $1 \%$ levels of significance. The observations have been displayed in table 5 . The $t$-test results also vindicate that both moisture and $\delta v$, oxygen $\delta v$, oxygen plus sulphate sulphur versus $\delta v$ and oxygen plus pyritic sulphur versus $\delta v$ show significant relations as the observed values of $t$ was greater than the tabulated value of $t$ (table 4). 
(a)

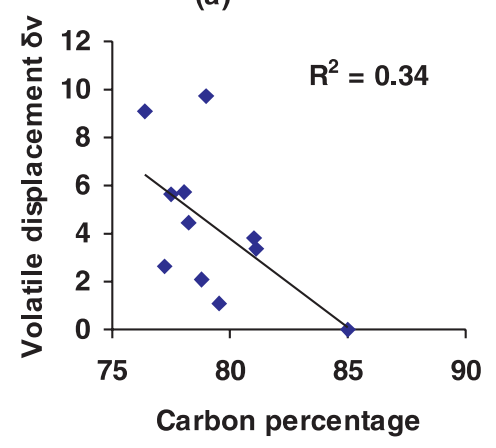

(c)

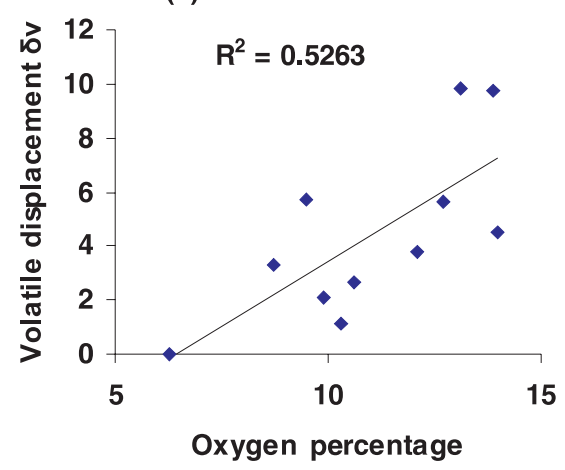

(e)
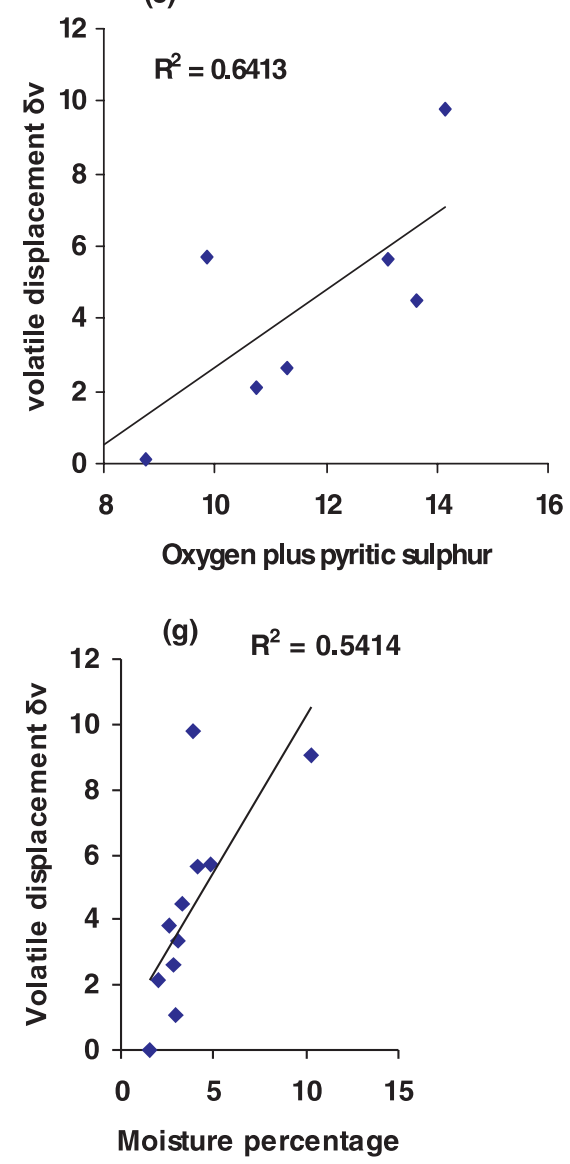

(b)

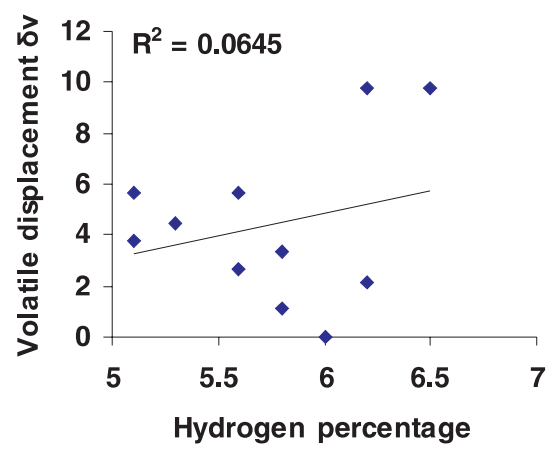

(d)

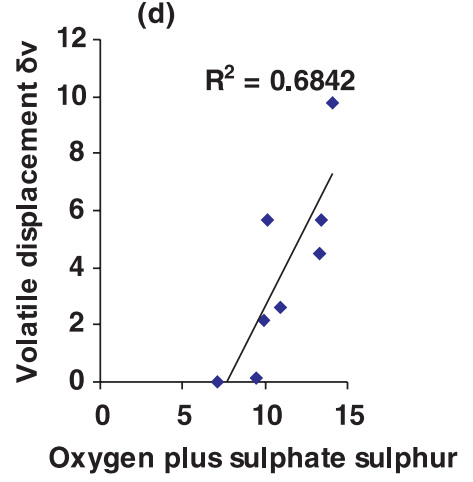

(f)

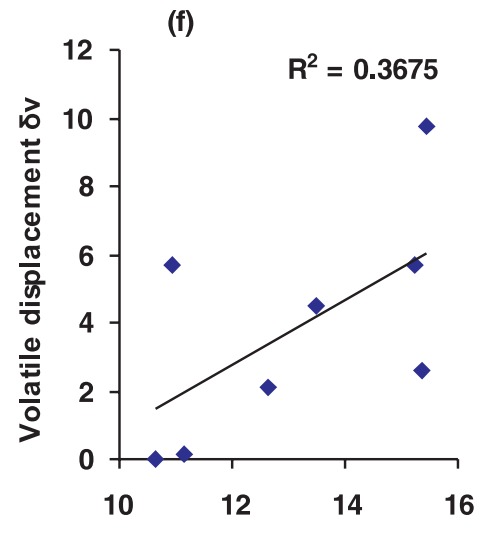

Oxygen plus organic sulphur

(h)

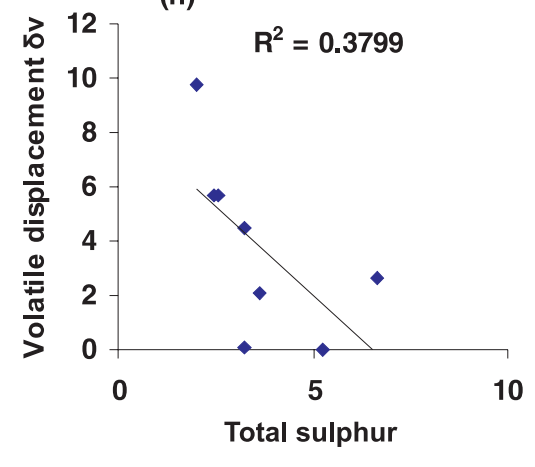

Figure 3. Correlation between: (a) carbon and $\delta v,(\mathbf{b})$ hydrogen and $\delta v,(\mathbf{c})$ oxygen and $\delta v$, (d) oxygen plus sulphate sulphur and $\delta v,(\mathbf{e})$ oxygen plus pyritic sulphur and $\delta v$, (f) oxygen plus organic sulphur and $\delta v$, (g) moisture and $\delta v$ and (h) total sulphur and $\delta v$. 
Table 1. Coalfields of Meghalaya (after Chandra et al 1983).

\begin{tabular}{|c|c|c|c|c|}
\hline Area & Colliery & Coalfield & Stage & Age \\
\hline Jaintia hills & $\left\{\begin{array}{l}\text { Bapung } \\
\text { Lumshnong } \\
\text { Borsora } \\
\text { Rongshokham }\end{array}\right.$ & $\begin{array}{l}\text { Bapung } \\
\text { Lumshlong } \\
\text { Langrin } \\
\text { Mawsynram }\end{array}$ & $\begin{array}{l}\text { Theria } \\
\text { Sylhet } \\
\text { Sylhet } \\
\text { Sylhet }\end{array}$ & $\begin{array}{l}\text { Palaeocene } \\
\text { Middle to Lower Eocene } \\
\text {-do- } \\
\text {-do- }\end{array}$ \\
\hline Khashi hills & $\left\{\begin{array}{l}\text { Jathan } \\
\text { Mawlong } \\
\text { Laitryngew }\end{array}\right.$ & $\begin{array}{l}\text { Ishamati } \\
\text { Laitryngew }\end{array}$ & $\begin{array}{l}\text { Sylhet } \\
\text { Sylhet }\end{array}$ & $\begin{array}{l}\text {-do- } \\
\text {-do- }\end{array}$ \\
\hline Garo hills & $\left\{\begin{array}{l}\text { Siju } \\
\text { Nangalbibra }\end{array}\right.$ & $\begin{array}{l}\text { Siju } \\
\text { West Daranggiri }\end{array}$ & $\begin{array}{l}\text { Tura(basal) } \\
\text { Tura (basal) }\end{array}$ & $\begin{array}{c}\text { Lower Eocene } \\
\text {-do- }\end{array}$ \\
\hline
\end{tabular}

Table 2. Chemical analyses of the coals of Meghalaya (after Chandra et al 1983).

\begin{tabular}{|c|c|c|c|c|c|c|c|c|c|}
\hline \multirow[b]{2}{*}{ Coalfield } & \multirow[b]{2}{*}{ Seam no. } & \multicolumn{2}{|c|}{ Air dried basis } & \multicolumn{6}{|c|}{ Dry mineral matter free basis } \\
\hline & & $\%$ Ash & $\% \mathrm{M}$ & $\% \mathrm{C}$ & $\% \mathrm{H}$ & $\% \mathrm{O}$ & \%V.M.(Exp). & $\%$ CalVM & $\delta v$ \\
\hline \multirow[t]{2}{*}{ Nangalbibra } & II & 3.80 & 4.50 & 77.50 & 5.10 & 12.70 & 51.00 & 45.34 & 5.66 \\
\hline & I & 8.50 & 8.20 & 76.40 & 6.50 & 13.10 & 49.30 & 58.38 & -9.08 \\
\hline Siju & Wait Nala section & 3.56 & 5.80 & 79.00 & 6.20 & 13.90 & 42.20 & 51.97 & -9.77 \\
\hline \multirow[t]{2}{*}{ Langrin } & II & 3.00 & 6.80 & 78.20 & 5.30 & 14.00 & 47.90 & 43.41 & 4.49 \\
\hline & I & 2.35 & 5.30 & 81.00 & 5.10 & 12.10 & 40.90 & 37.82 & 3.08 \\
\hline Mawsynram & Rongshokham section & 4.00 & 12.53 & 78.03 & 5.60 & 9.50 & 52.50 & 46.80 & 5.70 \\
\hline \multirow[t]{4}{*}{ Laitryngew } & IV & 2.30 & $11.30)$ & & & & 45.00 & 45.12 & \\
\hline & III & 3.50 & 6.90 & 81.10 & 5.80 & 8.70 & 38.20 & 45.12 & -3.34 \\
\hline & II & 3.00 & 14.80 & & & & 40.60 & 45.12 & \\
\hline & I & 1.60 & 25.60 & & & & 43.30 & 45.12 & \\
\hline Ishamati & & 1.80 & 9.15 & 78.80 & 6.20 & 9.90 & 50.10 & 52.22 & -2.12 \\
\hline \multirow[t]{2}{*}{ Bapung } & II & 2.50 & 7.25 & 77.20 & 5.60 & 10.60 & 45.20 & 47.83 & -2.63 \\
\hline & $\mathrm{I}$ & 2.50 & 12.50 & 79.50 & 5.80 & 10.30 & 48.20 & 47.10 & 1.1 \\
\hline Lumshnong & & 1.30 & 10.94 & 85.00 & 6.00 & 6.30 & 42.40 & 42.41 & -0.01 \\
\hline
\end{tabular}

Table 3. Sulphur concentration in Meghalaya coals (after Chandra et al 1983).

\begin{tabular}{|c|c|c|c|c|c|c|c|c|}
\hline Coalfield & Ps & $\mathrm{Ss}$ & Os & $\mathrm{O}_{2}$ & $\mathrm{O}_{2}+\mathrm{S}_{\mathrm{s}}$ & $\mathrm{O}_{2}+\mathrm{Ps}$ & $\mathrm{O}_{2}+\mathrm{Os}$ & $\mathrm{Ts}$ \\
\hline Nangalbibra & 0.05 & 0.32 & 2.18 & 13.05 & 13.37 & 13.10 & 15.23 & 2.55 \\
\hline Siju & 0.26 & 0.18 & 1.55 & 13.90 & 14.08 & 14.16 & 15.45 & 1.99 \\
\hline Langrin & 0.58 & 0.21 & 0.46 & 13.05 & 13.26 & 13.63 & 13.51 & 3.25 \\
\hline Mawsynram & 0.37 & 0.66 & 1.43 & 9.50 & 10.16 & 9.87 & 10.93 & 2.46 \\
\hline Laitryngew & 0.55 & 0.73 & 2.63 & 8.70 & 9.43 & 9.25 & 11.33 & 3.22 \\
\hline Ishamati & 0.85 & 0.03 & 2.74 & 9.90 & 9.93 & 10.75 & 12.64 & 3.62 \\
\hline Bapung & 1.06 & 0.67 & 5.10 & 10.25 & 10.92 & 11.31 & 15.35 & 6.83 \\
\hline Lumshnong & 0.82 & 0.08 & 4.33 & 6.38 & 7.15 & 7.20 & 10.71 & 5.23 \\
\hline
\end{tabular}

$\mathrm{O}_{2}=$ oxygen, $\mathrm{Ss}=$ sulphate sulphur, $\mathrm{Ps}=$ pyritic sulphur, Os = organic sulphur, TS = total sulphur.

In other words, volatile displacement values increase with the increase of oxygen, oxygen plus pyritic sulphur, oxygen plus sulphate sulphur and/or moisture. This leads to the conclusion that marine environment and then recession of sea was responsible for oxidation and weathering and replacement of sulphur by oxygen, which increased the volatile displacement values. There might have been frequent migration and regression of sea water in the past on the coal deposit and as a whole the palaeoenvironment of deposition was more like in an estuarine.

\section{Conclusions}

The following conclusions are drawn:

- Meghalaya coals have much lower ash content than the best quality coals of the country and their calorific value exceeds some of the best 
Table 4. Observed $R$ and corresponding t-values based on six $(N-2)$ degrees of freedom.

\begin{tabular}{cllcl}
\hline Fig. no. & Correlation & $R^{2}$ & $t($ calculated $)$ & Inference \\
\hline 3 & $\% \mathrm{C}$ and $\delta v$ & 0.34 & 1.7577 & Insignificant \\
4 & $\% \mathrm{H}$ and $\delta v$ & 0.0645 & 0.6429 & Insignificant \\
5 & $\% \mathrm{O}_{2}$ and $\delta v$ & 0.5263 & 2.5818 & Significant \\
6 & $\% \mathrm{O}_{2}+\mathrm{S}_{\mathrm{S}}$ and $\delta v$ & 0.6842 & 3.5710 & Significant \\
7 & $\% \mathrm{O}_{2}+\mathrm{P}_{\mathrm{S}}$ and $\delta v$ & 0.6413 & 3.2751 & Significant \\
8 & $\% \mathrm{O}_{2}+\mathrm{Os}$ and $\delta v$ & 0.3675 & 1.8672 & Insignificant \\
9 & $\% \mathrm{M}$ and $\delta v$ & 0.5414 & 2.6609 & Significant \\
10 & $\% \mathrm{Ts}$ and $\mathrm{d} v$ & 0.3799 & 1.9174 & Insignificant \\
\hline
\end{tabular}

Tabulated value of $t$ at $5 \%$ level of significance $=2.4469$.

Tabulated value of $t$ at $1 \%$ level of significance $=1.9432$.

grade coal, but the problematic aspect is their high sulphur content.

- The Meghalaya coals are abnormal in nature and the causes of abnormality may be weathering and oxidation triggered by marine environmental effect.

- Weathering and oxidation helped in the replacement process of oxygen and sulphur which increased the volatile displacement in these coals.

- The significant correlations between moisture and $\delta v\left(R^{2}=0.5414\right.$ and $\left.t=2.6609\right)$, oxygen and $\delta v\left(R^{2}=0.5263\right.$ and $\left.t=2.5818\right)$ oxygen plus sulphate sulphur and $\delta v\left(R^{2}=0.6842\right.$ and $t=3.5710$ ), and oxygen plus pyritic sulphur and $\delta v\left(R^{2}=0.6413\right.$ and $\left.t=3.2751\right)$, vindicates that displacement was controlled by weathering and oxidation.

- The abnormality in Meghalaya coals induced by sulphur opens up the possibility for delineating sulphur poor/high $\delta v$ coal horizons for exploration amidst low $\delta v$ horizons.

\section{Acknowledgements}

The author is grateful to Dr D Chandra, Emeritus Professor (Retd), Indian School of Mines, Dhanbad for encouragement and guidance to prepare the manuscript. Thankful acknowledgements are due to esteemed reviewers, Dr D K Sharma and other anonymous reviewers for their constructive suggestions, and to Dr H C Sheth, Associate Editor for his sincere critical review and suggestions to bring the manuscript to its final form. Thanks are also due to Prof L N Sahoo, Department of Statistics, Utkal University for his help in statistical interpretation.

\section{References}

Behera P 1991 Geology of the Ib-valley coalfield with special reference to spontaneous combustibility of different coalseams; Unpubl. Ph.D Thesis, Indian School of Mines, Dhanbad, India.

Chandra D, Mazumdar K and Basumallick S 1983 Distribution of sulphur in the tertiary coals of Meghalaya; Int. J. Coal Geol. 3 63-75.

Chandra D and Gupta U P 1976 Volatile displacement of weathered coals; Fuel 55 84-85.

Chandra D and Srivastava G P 1980 Volatile displacement of Burnt coals, J. Geol. Soc. India 21 306-310.

Chandra D, Rajaratnam S and Handique G K 1997 Coalification trend of Oligocene coals of Northeast India; Int. J. Coal Geol. 69(3) 251-256.

Ghosh D 1976 Palaeocene reef rock complex of Meghalaya and its oil potentialities; Sci. and Cult. 43.

Niyogi C 1989 Geology of Talcher coalfield with special reference to spontaneous combustion; Unpubl Ph.D Thesis, Indian School of Mines, Dhanbad, India.

Seyler C A 1938 Petrology and the classification of coal: Pts I \& II; Proc. S Wales Inst. Engrs. 53(4) 254-327. 